DANDELION

postgraduate arts journal \& research network

VOLUME 6 NUMBER I AUTUMN 2015
Dr CARla CRUz is an artist living in London. She holds a practice-based PhD from Goldsmiths, University of London with a project titled: 'Democracy a (Non) Artistic Intervention? Attempts to Perform Democracy Through Art'. Recent projects include the Walthamstow Performing Arts Collective residency at 38 Hoe Street, London and All My Independent Women.

carlabarroscruz@gmail.com

Article

\title{
Co-agency in Collaborative Art Projects
}

\author{
Dr Carla Cruz
}

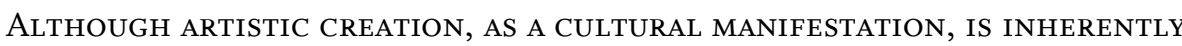
COLLECTIVE AND OFTEN COLLABORATIVE, THE PERVASIVE IMAGINARY WITHIN THE ARTWORLD (OR BETTER, MAINTAINED BY THE ARTWORLD'S MAIN MANIFESTATION: the market oriented artworld) is that the nature of the creative process is singular and individual, i.e. solitary.

If traditionally artists have been seen as individuals with specific manual skills, since the nineteenth century the artist has been seen as a 'special kind of person', with the emphasis less consigned to her skills and more to her sensibility. ${ }^{1}$ As Raymond Williams affirms:

From artist in the new sense there were formed artistic and artistical, and these, by the end of the nineteenth century, had certainly more reference to 'temperament' than to skill or practice. ${ }^{2}$
\end{abstract}

It is from this Romantic conception of the artist as an autonomous genius that artists came to see themselves as "agents of the "revolution for life," in their capacity as bearers of the creative imagination.. ${ }^{3}$ This model had several challenges, from the feminist critique of the artist ideal based on the white male middle-class artist, exposed by, among others, Linda Nochlin and Griselda Pollock, ${ }^{4}$ to poststructuralist suspicion of the existence of individual authorship, emphasising the role of the reader against the artist's custody of meaning and agency, as Roland Barthes expounded in The Death of the Author. ${ }^{5}$ Writer and artist Trinh T. Minh-ha poignantly reveals this problematic 
surrounding the author:

Laying emphasis on the prestige of the individual and on the search for an explanation of the work in the wo/man who produces it (thereby perpetuating the myth of the original writer), literature remains completely dominated by the sovereignty of the author. On the one hand, the castrating objectivism of the 'universal' writer; on the other hand, the obsessive personalism of the 'singular' writer. ${ }^{6}$

The myth of the original writer/artist, and the insistence of reading an artwork based on her biography reveals the persistent custody over the meaning and usage of the work by the author instead of the audience. Minh-ha suggests that the artist (as author) only exists through the work. The work itself is of importance here and the relationships it can establish, independently of its author, with others. I am interested in the circulation of cultural manifestations independently of who has 'made it'. But as Minh-ha affirms, '[a]s long as the belief in the sacred origin of writing and the religious principle of hidden meanings prevail,' the reign of the author, or for what matters here, the circulation of artworks based on artists' reputations, will not wane any time soon. One of the strategies employed by artists to address this problematic is to collaborate. Curator Maria Lind finds that artists involve themselves in collaboration or collective practices because 'for some this offers an alternative to the individualism that dominates the art world, for some it is understood as a way of re-questioning both artistic identity and authorship through selforganization'. ${ }^{7}$ However, she also rightly asks, 'to what degree can collaborative practices claim agency against the cult of the individual? ${ }^{8}$ Furthermore, as artist Gregory Scholette points out, we should not forget that the artworld has the remarkable capacity of incorporating its own critiques and it does not matter how 'obscure or seemingly radical one's creative activity may be there is an avaricious interest at work within the art world's restricted economy, a hunger not only for the new, but for everything. ${ }^{, 9}$ Art critic Craig Owens quotes the artist Michael Asher, positioning 'the artist' as just one role among many in the production of his 1977 exhibition at the Van Abbe Museum in Eindhoven:

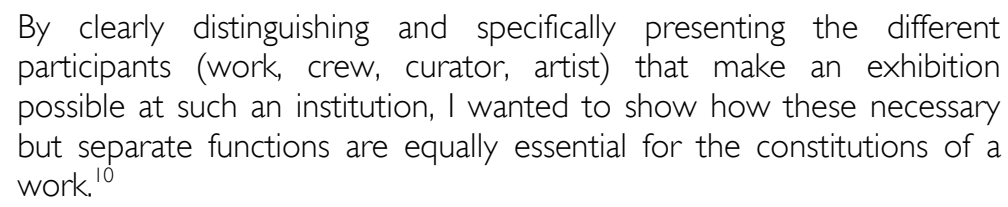

In this statement Asher is affirming that art production is inherently collective. Nonetheless, Owens stresses, this should not serve to encourage artists to collaborate among each other, rather it should help to defetishise the work of art. So, even if artistic creation is seen as inherently collective and often collaborative, the pervasive imaginary within the artworld is still that the nature of the creative process is singular and individual. This makes authorship appear as an act of power. The artist Susan Kelly, speaking about authoring projects in the context of social movements, suggests that authoring is appropriating collective knowledge and is often experienced as profoundly patronising and alienating for those involved [...] and creating divisive hierarchical splits', while, as Sholette highlights, the artworld is increasingly unequal and based on the success of a few (individual artists or collectives) because it generates artistic value from scarcity. ${ }^{11}$ That is, calculated scarcity and exclusivity are tools adopted by the art market to attain higher profits, by following the capitalist principles of scarcity and need to increase wealth 
accumulation.

Sholette argues that in the current artworld system, there can only be a few successful artists and a vast majority of semi-professional and amateur ones. The artworld in such a view reflects the 'ultra-competitive rules of business, as opposed to the collaborative networking of culture. ${ }^{12}$ This understanding of the artworld, and the fact, as Sholette points out, that 'the growing surplus art producers apparently prefer to survive by helping to reproduce familiar hierarchies, the same symbolic and fiscal economic system that guarantees most of them will fail' ${ }^{13}$ maintains an artworld structured on neoliberal values and reliant on 'making contacts' and professional reputation. ${ }^{14}$ That is, the artist is at the centre of the art system; it is her social value that gives art its added value and artistry. Suhail Malik argues that 'art can't get out of Capital if it deals with added value, or with artiness. ${ }^{15}$ Authorship thus appears as an over-valorized mechanism of accreditation of what can be understood as art.

Willing to contradict this tendency, as an artist, I have tried to get rid of myself, share my own process of artistic creation, disseminate authorship and abolish my authority. However the latter proved to be counterproductive, as I will explain in the following section. I have been suspicious of the privileging of the role of the artist and its custody of representing the world. To challenge that privilege I have attempted to flatten the borders between artist and audience. However my experiences of the democratization of my practice have included encountering constraints established by the artworld's institutions and structures. We know that the artworld is a multiverse rather than a universe, although as producers in the arts we are faced with some conceptual structures that render some of our experiences invisible, un-artistic, amateur, unpaid or forcefully voluntary, marginal and so on, without constituting a sense of belonging to an alternative scene or a different one, but more a sense of exclusion from a desired circle - the artworld. This singular artworld benefits from an anonymous creative mass. It praises inclusivity, but remains exclusive. In addition, I wanted to understand my role as an artist in the reproduction of those structures, thus the consequences of sharing authority along with authorship seemed to point me into the right direction.

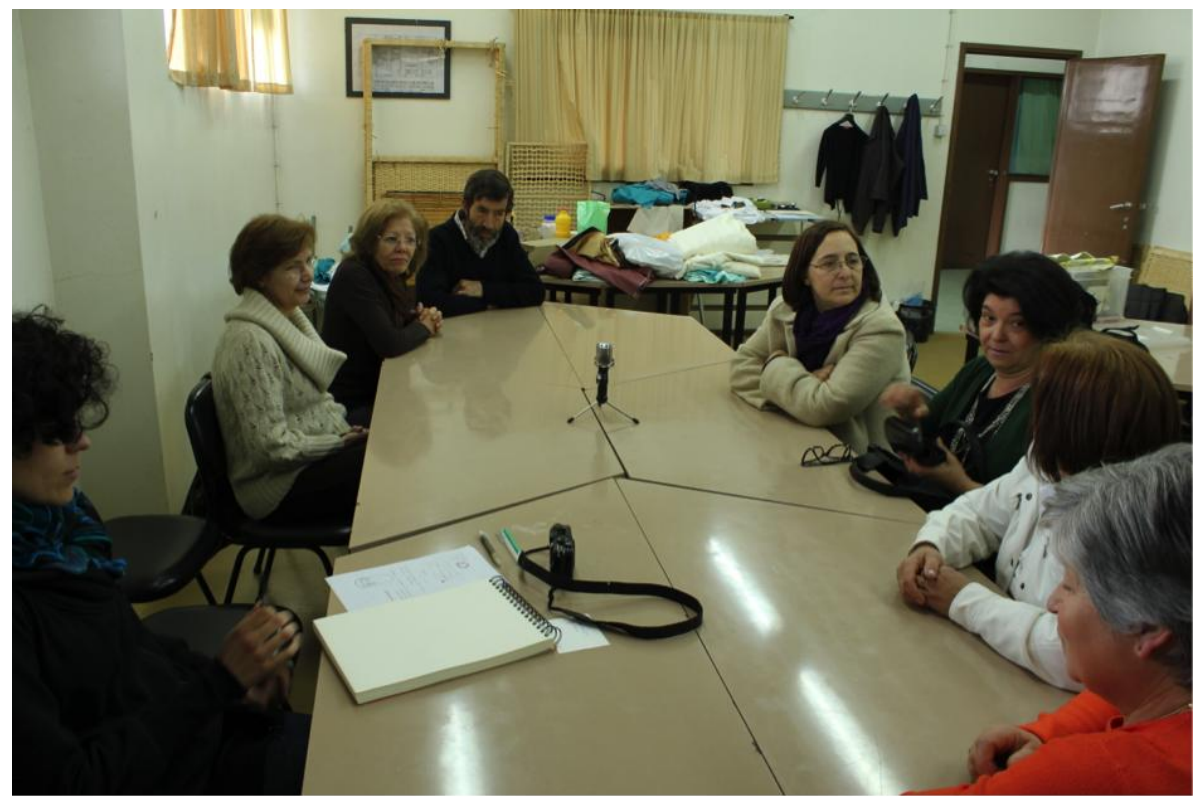

Figure 1. Rastilho's working session, March 2012. 


\section{Rastilho / RASTILHO}

In 2011 I was invited to be part of the exhibition project: ReaKt Views and Processes (2012), (ReaKt), curated by Gabriela Vaz-Pinheiro for Guimarães 2012, European Capital of Culture. ReaKt's 'aim was to produce an encounter of different artistic approaches to the very idea of context, of the transference of meaning, of the possibilities of positioning artistic practice in the contemporary world. ${ }^{16}$ The project I proposed, provisionally titled Rastilho, ${ }^{17}$ aimed to explore the issues related to the demobilization of industrial production in Portugal, the weakening of labour and the consequent feminization of poverty and, through these issues, to create a collective artistic gesture. The project required the participation of people from Guimarães who were unemployed at the time - the call for unemployed people to take part in this project was both a matter of availability to take part full-time and because unemployed people play a very important role in the matters proposed for discussion.

I found most of the participants within the local group Tecer Outras Coisas (Weaving Other Things - TOC), a group of skill sharing, composed of eight people, mainly women, based at Coelima, a textile factory in PevidémGuimarães. TOC is constituted by seven women and one man, all of whom were unemployed or retired from the textile industry; its goal is to create a platform for the transfer of skills and know-how between its members to find work within the field of garment production for fashion, crafts, theatre and the arts. The local visual artist and teacher, Max Fernandes, who initiated TOC in 2010, introduced me to the group. To these eight participants, five other women connected to the textile industry in the Vale do Ave joined. ${ }^{18}$ The project was initiated in December 2011 and happened throughout 2012 in a series of group meetings. After a first meeting with the group of voluntaries to confirm their interest in participating in my project, I devised four concrete working sessions. My goal with these sessions was not only to discuss the proposed themes but also to look for a common language that we would create as a group and that would allow us to arrive at a common artistic gesture. The project aimed at promoting a growing autonomy on the part of the participants in relation to their role; I ideally hoped to merge my contributions with the group's in order to allow for a collective creation. Accordingly, in my proposal, I would not be the author of the final public gesture, rather, in collaboration with the group of participants; my name would be just one among others. In this way, on the one hand, I intended to distinguish our approach from others where the participants are in some way performers of a project clearly outlined in advance by the artist; and on the other, to highlight my critique of the artist as author as the privileged source of meaning and value of an artistic/cultural product.

\section{From proposal to praxis The group}

In December 2011, together with Pedro Silva from ReaKt's production team, I met the eight people from the local community and members of TOC, seven women and one man, as well as Max Fernandes. When TOC confirmed their interest in taking part in the project proposed to ReaKt, we collectively decided how to distribute the money allocated for participants' fees and decided to enlarge the group to twelve participants. ${ }^{19}$ They invited five other women from their local community to join the group, taking into consideration that 
everyone was being paid, i.e. they invited women they knew, whom they thought would be interested in the process and available, but fundamentally women that would need the money - these women were either unemployed and at the end of their benefits period, or had a meagre pension. TOC is in itself composed of a dynamic group of unemployed and retired people who volunteer on numerous local associations, and who have been, together with Max Fernandes, involved in projects with fashion design students, artists and local institutions in the production of garments and theatre costumes. ${ }^{20}$ With the intention of fostering an atmosphere of collective practice, the main task was to integrate myself and these five other women in TOC's existing dynamics.

\section{The plan}

The suggested title for the project, rastilho (fuse), is a term from the textile industry jargon. It refers to an off-cut about 20 metres long which is permanently in the machines and to which a new piece of fabric to be worked upon is attached to. Due to the complexity of the textile machines, and the adjustments needed at the beginning of every working session, the fuse makes the beginning of a working session quicker and saves that same amount of good fabric. This off-cut stays in use for a very long time and bears the marks of different prints and colours. My interest in that term is related to the possible analogies between its function and the situation of middle-aged women in the textile industry in Portugal. Once useful actors within the industry those women have been discarded, and just like the rastilho they bear the traces of their experience and knowledge, however these are denied the opportunity to be used as transferable skills. ${ }^{21}$

I suggested the themes for the first sessions in order to initiate a dialogue that would lead us to explore what could become our common interests and, from there, to be able to create an artwork collectively. The first session was spent exploring the notion of rastilho as multi-layered and as a conductor. The second session explored ideas around work. The third session brought to the table the issue of gender divisions present in the work place and in the private domain. The fourth session discussed issues of circulation: of commodities and people. By the time of the fourth session, the flow of conversations did not need my prescriptive directions anymore. The group was generating its own dialogue, remaining focused on the aim: the production of an artistic gesture for ReaKt. Throughout the process I kept insisting on the theme of the world-of-labour, but the group was very resistant to it. Some of the participants refused to be framed merely as unemployed or former workers of an industry in decline. They refused to be taken as a token of the Portuguese financial crisis. However, the alternatives they suggested did not reflect the variety and richness of the group's experiences and due to the time frame could become very superficial. ${ }^{22}$ While I was attempting to explore a process of shared practice I was not prepared to let them go in the direction of what I thought might result in a simplistic gesture. The power relations at play in this divergence ended up being the productive motor of the process, as will later be explored, and opened up the space of reflection on my own role in the process. 


\section{The deviation from the plan}

The many parallel conversations that took place could, at any time, become the centre of discussion throughout our sessions. During one such lively debate on what theme the collective creation should address, a lateral idea emerged. An individual expressed her sadness at seeing the old primary school empty. The village's old primary school that had been offered by a local industrialist to the community in the 1930s was closed in 2009, and following our use of it for the RASTILHO project, is once more not in use. ${ }^{23}$ After the initial expression of outrage towards the council's plan to house the existing public library in the building without public consultation, the group voiced the desire to make use of the building. This desire gave our search for an end result for Rastilho's process a shape, and we all gathered around an idea: to make use of the building by creating a space for teaching and learning, where everyone could be both teacher and student: a space for culture.

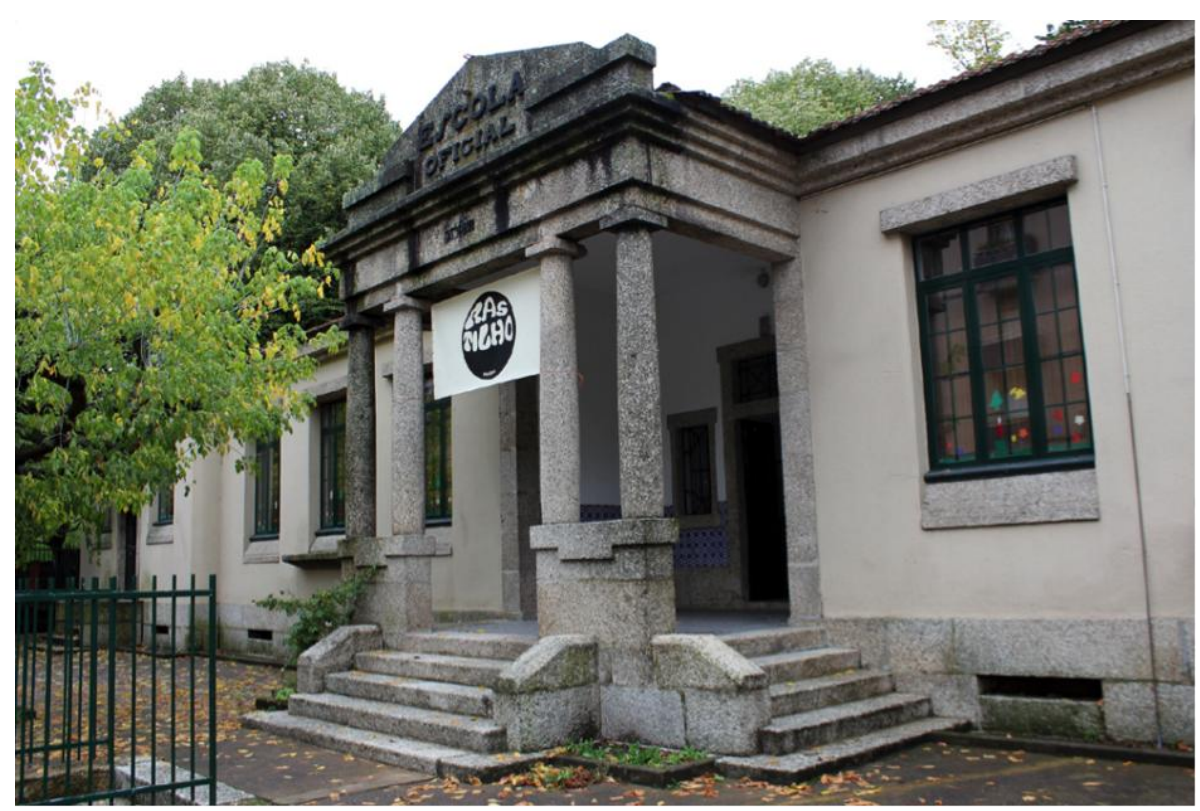

Figure 2. The School, Pevidém, September 2012.

\section{The change of plan}

In an attempt to problematize issues around individual authorship I proposed a project of collective creation of an artwork; but when the process forced the group to focus on itself, i.e. in its self-constitution as a group instead of the creation of a collective artwork, my role within the group changed. The group took the same name as the proposed project, RASTILHO (which, as previously mentioned, I have written in capital letters to better differentiate it from the initial project proposed). Within it, my role as an artist became more the role of a facilitator, the one who holds the keys to the institutions of art, the one who could use her privileged position in the artworld to grant the group access to the public building. The initial request to use the school building, made by RASTILHO, on an independent basis, to the local authorities, was denied. It was only when mediated through ReaKts production team that eventually we got hold of the space for the duration of the exhibition. ${ }^{24}$ RASTILHO, the community group, used the fact that it was still understood by the local authorities and the production team of ReaKt as Rastilho, the artistic gesture proposed by Carla Cruz, to negotiate with the council, through ReaKt's 
production team, using the space of the empty primary school before it is turned into a library. ReaKt's production team was already in conversations with the council regarding the installation of other artist's projects in different public spaces and buildings. The temporary nature of these projects made them easier to be accepted by different stakeholders. We, RASTILHO, took advantage of this on-going process and requested the use of the building for something that broke with the notion of an artistic installation in a public space. Moreover, we were hopeful that the local authorities would realize the benefits of the proposed activities by and for the community and thus the occupancy agreement would be extended. However, the fact that we presented ourselves as an artistic gesture backfired. As the council never discussed the occupancy with the group itself, at the end of the Cultural Capital events it was very easy to dismiss the request for further usage, which they did by asking the project to end and by inviting the group to make an official proposal through a different and more bureaucratic avenue.

\section{The withdrawal attempt}

Having a dual status as a group and community space and intervention in an international exhibition, I decided that my name, as individual artist, should be removed from all communication material, and substituted by the newly formed collective's name: RASTILHO. I asked ReaKt's production team to take my name off the press release, invitation and catalogue and replace it with RASTILHO's, because from that moment on, the authorship of what would become public - the group's activities at the school - was not mine. This decision was my initiative, and I wanted it to be a radical one, i.e. not give information about the process of becoming RASTILHO in ReaKt's communication material and documentation centre. This action, on the one hand, would question the very notion of cultural production based on the model of the individual artist, and on the other it would prevent the group's activities being merely observed instead of participated in. However, the group wanted to keep the genesis of its formation as my initiative and although RASTILHO substitutes my name as the author of the final artistic gesture performed for ReaKt, the biography that appears in the catalogue is still that of Carla Cruz. ${ }^{25}$

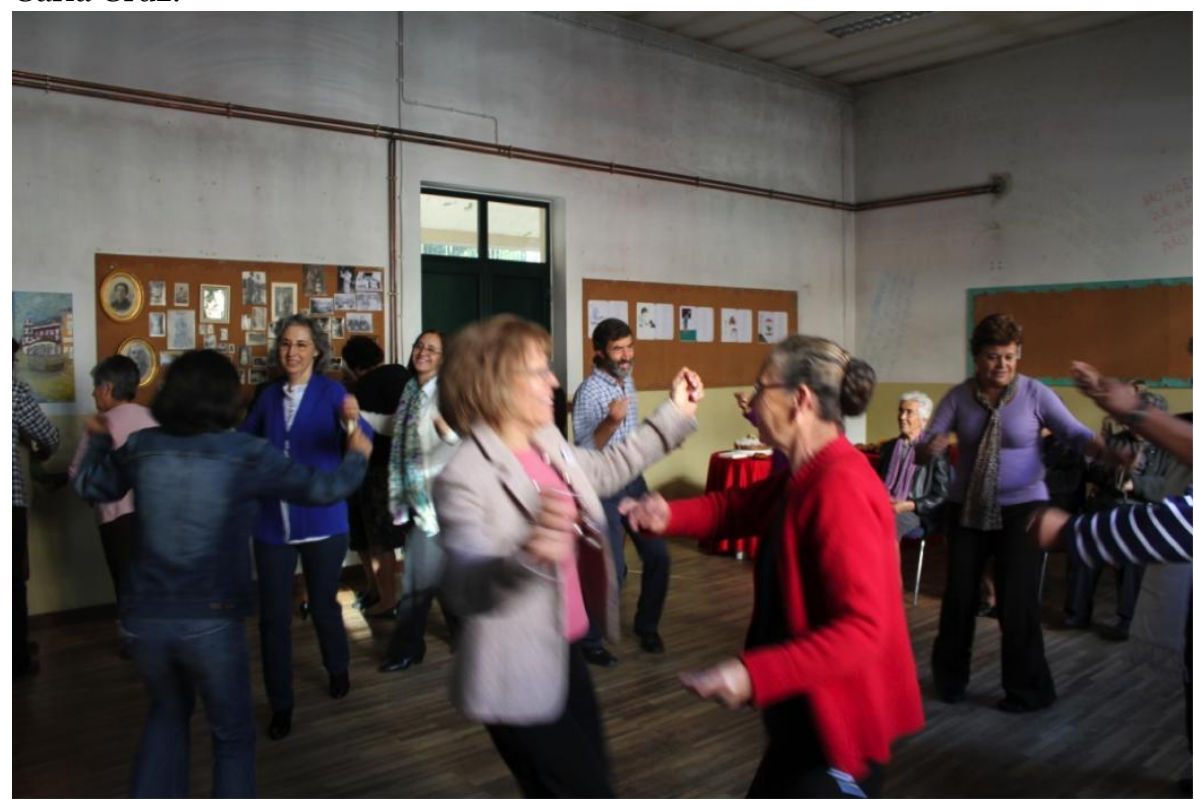

Figure 3. Folk dance session, October 2012. 


\title{
The outcome
}

The first action, after the group had decided to become RASTILHO, was to create its charter of principles. Based on other collectives' examples and a conversation, at my request, with Oporto-based communitarian and selfmanaged group ES.COL.A da Fontinha, ${ }^{26}$ RASTILHO defined itself as an organic, horizontal group: ' $[\mathrm{w}] \mathrm{ith}$ no set duration and not-for-profit that aims to promote the collective production of culture. ${ }^{27}$ At this moment, they left behind the fact that they were volunteering in the production of an artwork by an artist to seize the production of culture according to their own definition, and I left behind my desire to lead them, as a group, towards emancipation as art producers.

On 20 October 2012 the group opened up the space to the community. They wrote about it in their journal:

\begin{abstract}
The population turned up in large numbers, socialising and remembering the school that many of them attended. There was a lot of folk dancing and entertainment. By coincidence, on that same day, Pevidém's Marching Band, who celebrated their anniversary, stopped in front of the school, playing for all of those who were there. ${ }^{28}$
\end{abstract}

From then on, and on the main room: Mondays were reserved for IT sessions and the organization of RASTILHO's journal; Tuesdays were dedicated to the learning of Guimarães' embroidery; Wednesdays to crafts, such as floral displays; Thursdays to folk dancing and singing. Due to the high demand by the community, the space was also open on Fridays with drop-in sessions. In the adjacent room, the group organized thematic displays, such as 'The History of the Bee and the Honey', or paintings by local artists. In addition the room was used by people (in fact, exclusively men) to play card and board games. ${ }^{29}$

The desire, to give a community-use to an empty public building, catalysed the emergence of RASTILHO, but, more precisely, what generated its process of becoming were the continued exchanges between all the members of Rastilho. RASTILHO - the community group - emerged when the members of Rastilho - the group volunteering in an artist's project - generated its own modes of doing and relating. Thus, the production of the collective, RASTILHO, became intrinsic to the production of the self. As written in their journal:

\footnotetext{
The school's living space is managed by the community, and was set in motion by this initial group. The space, of multipurpose use, is modified according to the activities - programmed or spontaneous. Nonetheless, we must highlight, RASTILHO is not the space, it is the group; it is the movement that goes from one to the other, the movement that searches to understand, and share with, the other. ${ }^{30}$
}

The group here stresses exactly that it is through the production of itself, as a group, that they exist, not by the fact that they use the school building as a community space. Throughout the process of becoming RASTILHO, we (Max, Amanda Midori, an MFA student who joined the group when RASTILHO was formed, and I) wanted to promote the full autonomy of the group, as a community cultural group. Thus, we tried to be like any other member of the group, taking and sharing responsibilities, but eventually being only honorary members. 


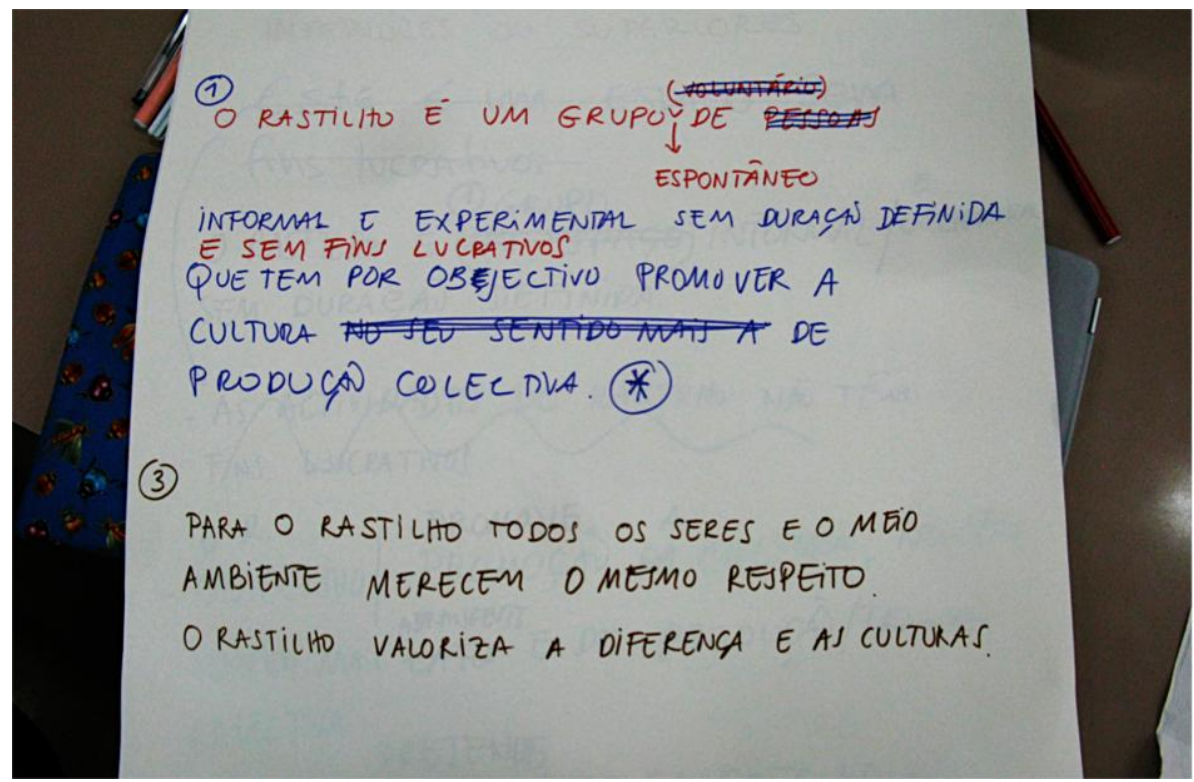

Figure 4. RASTILHO's charter of principles in progress, June 2012.

\section{The remainder}

RASTILHO used two of the four rooms of the school between September 2012 and January 2013, when the local council, because of the end of the Guimarães 2012, demanded the clearance of the space. That is, although the city council has promised to discuss the continuation of the use of the space by the community group, the conversations did not develop any further because the council later changed their position and declared that they would only dialogue with a collectivity with legal status. During three months, the group transformed the vacant school into a communitarian space where they promoted and hosted cultural and educational events. The group was only a legitimate user of the space when it was still seen as a contemporary work of art. Subsequently, even after proving the interest of the larger community in their activities, when they requested a continuation of the lease, it was denied on the basis that they had no institutional body. They were not a recognized association. ${ }^{31}$ But this is precisely what the group always refused to be and to become. RASTILHO does not want to be institutionalized. They refuse, even for the purpose of negotiating the space with the municipality, to be defined in such a fixed way. ${ }^{32}$

In the meantime, the school remains empty; at the time of writing this article, the group - enlarged with new members from the community - is liaising with a local association, which has the legal status necessary to renegotiate the use of the public building by the community. Today members of the group still meet every week to share knowledge and teach each other skills, but incorporated in other collectivities, such as Tecer Outras Coisas and church-related groups. 


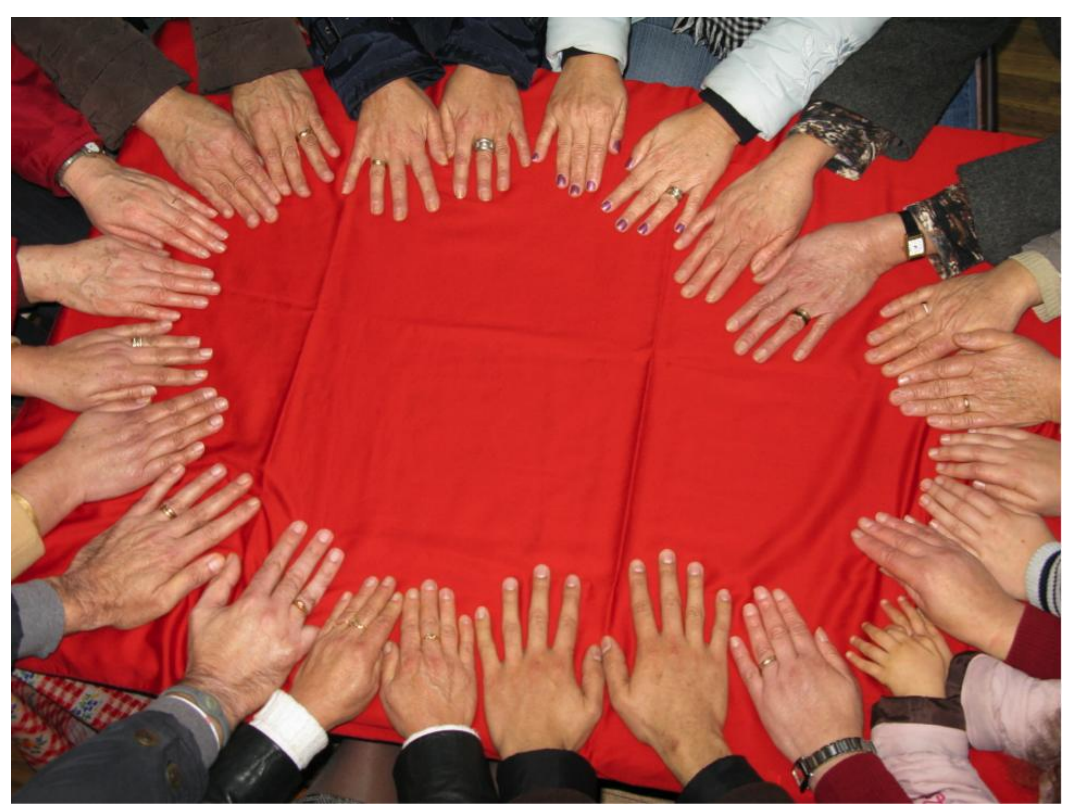

Figure 5. RASTILHO's self-portrait.

\section{Co-agency}

My initial aim for Rastilho was to form a group of collaborators for a project of collective artistic creation and present the result, authored by all of those involved, at ReaKt. Thus, through Rastilho I wanted to question the model of single authorship based on the individual artist - that constructed figure whose profile is still bonded to notions of geniality, individuality and masculinity. The initial plan was to generate a creative process that could be coauthored by all of those involved, and for that I imagined a breakdown of hierarchies where the group would slowly start to cohere. However, I was faced with the fact that attempting to share authorship did not necessarily remove me from a position of authority. One of the stumbling blocks to generating a horizontal environment, or what I thought then would be an environment of equality, was my position both as artist and initiator within the group. That is, both the generator of the collective process and the supposed specialist in arts that was called upon for the final decisions. The fact of also being considered the author of the project by ReaKt, enhanced the inequity. Authorship and authority seem to go hand-in-hand. Thus, not only did I promote conversations that could lead to a shared concern that could be translated into an artistic gesture, but I was also promoting the autonomy of the group, so that the final decision on that gesture could be truly collective and not dictated by the artists (Max and I). Conversely, even if my desire, as an artist and as a citizen, might be to promote, and be part of, an autonomous community space, this could only be achieved through the praxis of the community itself; a community that lobbied, organized, liaised, promoted, set up and animated the space, and finally enlarged the initial group. Here, our roles, and possible hierarchical positions, become complicated and agency was distributed between artist and non-artist participants.

Moreover, my critical attempt to disinvest the artist of her authorial/authoritarian position to subvert the mainstream version of art stumbles upon the fact that art is just a manifestation of the diversity of culture and not its sole representative. Thus, a subversive act within the field of art becomes a dominant gesture in the field of culture - the community does not need my intervention to produce culture, they are always and already 
producing it, despite my contribution to secure a venue for such production to happen publicly. On the other hand, and as Sholette affirms, 'the art world is at once more global and yet less varied, more visibly diversified and yet neither porous nor malleable in its aesthetic range, ${ }^{33}$ thus proposing 'popular culture' within the heart of high culture - ReaKt - opens up a space to question art and highbrow culture as intellectually edifying against popular culture as demeaning. Centre and margin are in fact constitutive of each other. Thus, we need to do away with lower/higher definitions of culture since the real challenge, according to Williams, is 'to ensure the means of life, and the means of community. But what will then, by these means, be lived, we cannot know or say. $^{34}$

\section{Notes}

Raymond Williams, Culture and Society (London, The Hogarth Press 1993), p. 44.

Williams, p. 44.

Williams, p. 42.

Linda Nochlin, 'Why Have There Been No Great Women Artists?', Art News, 69 (1971), 22-39; Griselda Pollock, 'Differencing the Canon: Feminism and the Writing of Art's Histories' (London: Routledge, 1999).

Roland Barthes, 'The Death of the Author' (1968), in Image Music Text (New York: Hill and Wang, 1977), 155-64.

Trinh T. Minh-ha, 'Woman, Native, Other: Writing Postcoloniality and Feminism' (Bloomington: Indiana University Press, 1989), p. 29.

Maria Lind, 'Complications; On Collaboration, Agency and Contemporary Art', in Public New Communities, 30 (2009), 53-73 (p. 53).

Lind, p. 53.

Gregory Sholette, 'Dark Matter: Art and Politics in the Age of Enterprise Culture' (London: Pluto Press, 2011), p. 213.

Craig Owens, 'From Work to Frame, or Is There Life After "The Death of the Author"?', in Beyond Recognition: Representation, Power, and Culture, ed. by S. Bryson and others (Berkeley: University of California Press, 1992), 122-29, (p. 134).

Susan Kelly, "But that was my idea!" Problems of Authorship and Validation', in Contemporary Practices of Creative Dissent, Parallax, 19 (2013), 53-49 (p. 6).

Sholette, p. 117.

Sholette, p. 119.

Suhail Malik, 'Is art really a commodity? Really Really?' [Talk, Goldsmiths University of London, 2010] (no page numbers).

Malik.

reakt.guimaraes 2012

To differentiate my initial proposal of its outcome, the collective, I will use Rastilho to refer to the proposal and RASTILHO to refer to the collective that emerged from this proposal.

The group, later enlarged, is composed of: Adelaide Guimarães, Adriana Prazeres, Alexandre Moreira, Amanda Midori, Carla Costa, Carla Cruz, Eduarda Costa, Fernanda Assunção, Albina Leite, Elisa Ferreira, Fernanda Freitas, Goretti Esteves, Lurdes Oliveira, Margarida Moreira, Maria José Novais, Max Fernandes, Tomás Lemos. The visual artist Max Fernandes joined the group from the beginning as a second moderator. During the process two students joined the sessions: Margarida Moreira, who was finishing her secondary education in graphic design, came to design the Logo with the group and Amanda Midori, an MFA student researching on art and the public space, came, through the programme of volunteers, in the late stage of my pregnancy, when I was prevented from following the process in situ, to help the group deal with ReaKt's production team. Vale do Ave is a sub-region integrated in the larger North Region, Portugal. Organized around the city Guimarães, this sub-region is densely populated and one of the most industrialized areas of the country. Vale do Ave is also one of the areas most affected by unemployment. 
$€ 7,500$ for production, together with ReaKt's team, I decided to use $60 \%$ of it in participants' fees.

20 The home-textile factory, Coelima, provides the fabrics, workspace and equipment.

21 Due to, among other reasons, the displacement of production to other parts of the world where labour is cheaper, it is upon these women that the worst face of unemployment falls. Being close to retirement age, without being too close, leaves them, on the one hand, with no prospects of finding a new job, and on the other, without the possibility of obtaining long-term benefits. One of the ideas put forward as a thematic focus was the fact that drinking fountains are disappearing from their local public space. The school building is located right at the heart of the locality of Pevidém. Donated by the local industrialist, Francisco da Cunha Guimarães, the school opened in 1934. The children were relocated to a bigger school, with better facilities, in 2009. The building, after planned renovations, will host the local public library, which is currently housed in a small space design for commercial use. In March 2012, the group had a meeting with the person responsible for the municipal libraries and in charge of Pevidém's School building: Francisca Abreu, councillor of Guimarães Education and Culture department. In this meeting we requested the use of the building while the future works for the new library were still on hold. The request was denied. It was only due to the negotiations by the production team of ReaKt that the space was officially granted and the keys given to the group in September 2012. The loan came with a very specific deadline, the end of Guimarães 2012. In the catalogue, and in spite of my request, RASTILHO appears as the proponent of itself - RASTILHO the occupiers of the public building - and discloses my participation in its genesis, but the biography in the final pages of the catalogue is of the artist whose name is Carla Cruz. ES.COL.A da Fontinha is the Self-managed Collective Space of Alto da Fontinha. Its goal was to 'create a space that is autonomous, self-managed, free, non-discriminatory and non-commercial, and open to different activities. These were the guidelines that lead the project Es.Col.A. [...] It was born with and for the neighbourhood, with and for the community'. The group occupied a vacant school in the Portuguese city of Oporto, which, after several negotiations and even a verbal agreement of use of the space by the municipality, was evicted by force in April 2011. In June 2012 five members of ES.COL.A came to Pevidém to talk with RASTILHO about their experiences. The talk, which was mainly to be about the practicalities of running a community-led space, ended up by being about the righteousness of occupation of public buildings. It resulted in heated debate, for RASTILHO's libertarian ideals are state affiliated whereas ES.COL.A's are more anarchic. RASTILHO's Charter of Principles (Unpublished 2012, no page numbers). Rastilho, Journal(Unpublished 2012), p. 4.

The group that used this space was exclusively male, and composed by men who already engaged in such activities outdoors in the public square. Being previously subject to the weather conditions, these men were assiduous users of the space, but I could not say they contributed much to the maintenance of RASTILHO. Rastilho, p. 2.

In Portugal, to be recognized as an official not-for-profit association, the group would have to have: a name; a designated minimum number of associates; write their own statutes; define an hierarchical internal structure - with president, vice-president, etc.; have a first meeting which would be recorded on the minutes book; apply to be considered and identified for tax purposes as a collective person; and finally, register within the civil registry and receive the 'collective person' card. From then on, have at least one annual members' meeting, recorded on the minutes' book and declare for tax purposes their annual revenues.

32 Although the municipality claims the reason why they could not let them use the space is the lack of an institutional body, i.e. a bureaucratic one, this was a red herring. ES.COL.A, went through the same process with Oporto's municipality, constituting themselves as an official association. Nonetheless, they were violently evicted and the building destroyed to the point of being unusable. Without the space, ES.COL.A nowadays organizes events in the local public square. 


\section{Works Cited}

Kelly, Susan, "'But that was my idea!" Problems of Authorship and Validation in Contemporary Practices of Creative Dissent', Parallax, 19 (2013), pp. 53-59.

Lind, Maria, 'Complications; On collaboration, Agency and Contemporary Art', Public New Communities, 30 (2009), pp. 53-73.

Malik, Suhail, Is art really a commodity? Really Really? [Talk, Goldsmiths, University of London, 2010], no page numbers.

Nochlin, Linda, 'Why Have There Been No Great Women Artists?', Art News, 69 (1971), pp. 22-39.

Owens, Craig, 'From Work to Frame, or Is There Life After "The Death of the Author"?', in Beyond Recognition: Representation, Power, and Culture, ed. by S. Bryson and others (Berkeley: University of California Press, 1992), pp. 122-29.

Pollock, Griselda, Differencing the Canon: Feminism and the Writing of Art's Histories (London: Routledge, 1999)

Rastilho, Journal (Unpublished 2012)

RASTILHO's Charter of Principles (Unpublished 2012)

reaKt.guimaraes2012 (website) < http://reakt.guimaraes2012.pt/> [accessed 12 May 2013]

Sholette, Gregory, 'Dark Matter: Art and Politics in the Age of Enterprise Culture' (London: Pluto Press, 2011)

Strategic Plan 2010-2012. guimaraes2012.pt. $<$ http://www.guimaraes2012.pt/index.php?cat $=12 \&$ sup $=7>$ [accessed 25 May 2013].

Minh-Ha, Trinh T., 'Woman, Native, Other: Writing Postcoloniality and Feminism' (Bloomington: Indiana University Press, 1989)

Williams, Raymond, Culture and Society (London: The Hogarth Press, 1993) 